\title{
NOTES ON THE LOCUSTIDÆ, WITH DESCRIPTION OF A NEW SPECIES.
}

BY WM. T. DAVIS, STATEN ISLAND, N. Y.

Whether they fill the listener with a train of happy thoughts, as Gilbert White says, or whether they produce a sadness because the days of summer are nearly gone, as Dr. Harris asserts, the songs of crickets and other Orthoptera have, nevertheless, the merit of always being interesting. An insect that can sing - that has something to say-even though it be the same, night after night, enjoys a sort of individuality, and this long discussion of the Katydids and the quiet murmur of the tree crickets, constitute one of the chief charms of our summer evenings. But they do not always sing or stridulate quite alike, and sometimes, too, their shrilling apparatus is slightly deformed or injured, producing some curious sounds when in use.

I once heard a Katydid whose singing apparatus was out of order, and the sounds given forth contrasted strangely with those of a rival male in an adjoining tree. Amblycorypha retinervis produces two somewhat different songs, or perhaps more correctly, varies the same song in time or extent of utterance, so that unless the same individual is listened to for some time, the notes might be attributed to different species. This insect often lays its eggs on the honeysuckle, and I once observed a female on the 16 th of Sept., ovipositing on a low tree by the road side, gradually biting the bark into a ridge, along which the eggs were laid, tile fashion.

On Staten Island, the first Conocephalus that is heard in the garden is ensiger, and with $i k-i k-i k$, as if sharpening a saw, enlivens low bushes and particularly the corn patch. This insect seems to especially delight in perching near the top of a corn-stalk and there giving forth its rather impulsive song. I have often watched one crawl, with many a spiral turn, up the stem, fiddling all the while. My notes on its first heard stridulation show considerable uniformity, and the average date may be taken as July $5^{\text {th. }}$

Conocephalus dissimilis is more of a low grass and weed loving insect than $C$. ensiger, and also comes later in the season. I have found this insect stridulating when its head was gone, picked off perhaps by some 
vagrant chick. The brown colored specimens are much more common in this species than in ensiger.

Conocephalus robustus resides for the most part mid the grass on sandy ground near the sea shore, though an occasional individual finds its way inland. Along the sea beach they stridulate in early afternoon, especially if slightly cloudy, and when approached they have a curious fashion of dropping to the ground. I have often found them, on such occasions, actually standing on their heads in the soft sand, leaning against the grass stems which grow so close together, without in any way holding on to them. Whether this position is intentional or not, I cannot say, but certain it is that when looked for from above they offer the smallest extent of their bodies to view and may thus escape many enemies.

I have found another Conocephalus on Staten Island, mid the cat-tails that grow on the salt meadows, and a specimen sent to Mr. Samuel H. Scudder was considered by that gentleman to be an undescribed species. This insect keeps very close to the ground, hiding well in the vegetation, and is not easily discovered. The sound produced when stridulating is very faint, not louder than that made by Gryllus abbrinatus, and I was. much surprised to hear such a faint song come from so large an insect. I have, in consequence of this faint song, named it the "slightly musical" Conocephalus.

C. exiliscanorus. A large species, brown or green, the tegmina in the brown specimens irregularly dotted with fuscous spots. Fastigium long, moderately pointed, bent downward at apex, slightly flattened and scabrous above with medial groove or depression, depending tooth at lower base of fastigium pointed. Pronotum scabrous. Tegmina moderately broad and slightly falcate. Hind femora with numerous spines beneath, the other femora with only an occasional abortive spine near tip.

Length of body (including head), $37 \mathrm{~m} . \mathrm{m}$.; of fastigium beyond front edge of eyes, $5 \mathrm{~m} . \mathrm{m}$.; of pronotal disk, $9 \mathrm{~m} . \mathrm{m}$.; of tegmina, $40 \mathrm{~m} . \mathrm{m}$.; of hind tibiae, 2 I m.m.; 2 ô.

This insect is allied to $C$. ensiger, but readily distinguished by the longer fastigium, the entire under surface of which, with the exception of the basal fourth, is of a deep shining black. 


\section{$2 \mathrm{BHL}$ Biodiversity Heritage Library}

Davis, William T. 1887. "Notes on the Locustidae with description of a new species." The Canadian entomologist 19, 56-57. https://doi.org/10.4039/Ent1956-3.

View This Item Online: https://www.biodiversitylibrary.org/item/22087

DOI: https://doi.org/10.4039/Ent1956-3

Permalink: https://www.biodiversitylibrary.org/partpdf/14695

\section{Holding Institution}

MBLWHOI Library

\section{Sponsored by}

MBLWHOI Library

\section{Copyright \& Reuse}

Copyright Status: NOT_IN_COPYRIGHT

This document was created from content at the Biodiversity Heritage Library, the world's largest open access digital library for biodiversity literature and archives. Visit BHL at https://www.biodiversitylibrary.org. 